2011

\title{
An Analysis of the Relationship between New Firm Formation and Economic Development in the Northeast Region of the United States
}

\author{
Saima Bashir \\ Saima.Bashir@mail.wvu.edu \\ Tesfa Gebremedhin \\ tgebreme@wvu.edu
}

Follow this and additional works at: https://researchrepository.wvu.edu/rri_pubs

Part of the Regional Economics Commons

\section{Digital Commons Citation}

Bashir, Saima and Gebremedhin, Tesfa, "An Analysis of the Relationship between New Firm Formation and Economic Development in the Northeast Region of the United States" (2011). Regional Research Institute Publications and Working Papers. 57.

https://researchrepository.wvu.edu/rri_pubs/57 


\section{Regional Research Institute}

\section{Working Paper Series}

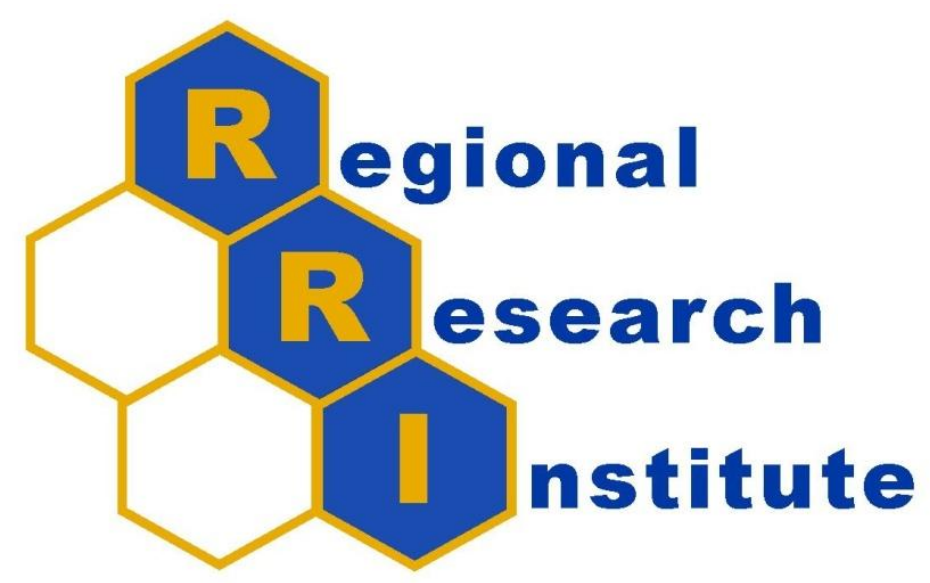

\section{An Analysis of the Relationship between New Firm Formation and Economic Development in the Northeast Region of the United States}

By: Saima Bashir, Graduate Student, and Tesfa Gebremedhin, Professor, Division of Resource Management, West Virginia University

Working Paper Number 2011-02

Website address: rri.wvu.edu

Submitted to the Southern Regional Science Association, March 2011,

New Orleans, Louisiana 


\title{
An Analysis of the Relationship between New Firm Formation and Economic Development in the Northeast Region of the United States
}

\author{
Saima Bashir and Tesfa Gebremedhin ${ }^{1}$
}

\begin{abstract}
The overall objective of this study is to provide policy makers with information on the role of new firm formation in the economic development in the Northeast region of the United States. This study identifies and estimates the impacts of new firm formation in the economic development of the Northeast region. The empirical model of this study is derived from the three-equation simultaneous model of Deller et al. (2001). In this study, Three-Stage Least Squares (3SLS) method is used to estimate the simultaneous equations model. The research findings indicate that population density and per capita income have a positive link with new firm formation. Higher population density and per capita income encourage entrepreneurs to start new firms in the region. This leads to an increase of new jobs, which is a positive contribution to economic development in the Northeast region.
\end{abstract}

Key Word: New Firm Formation; Economic Development; Northeast Region; Simultaneous Analysis

\footnotetext{
${ }^{1}$ Graduate Student and Professor, Division of Resource Management, West Virginia University.

The authors acknowledge and appreciate the review comments of Dale Colyer and Blessing Maumbe.

Selected paper presented at Southern Regional Science Annual meeting March 2011 New Orleans, Louisiana.

This research was supported by Hatch funds appropriated to the Agricultural and Forestry Experiment Station, Davis College of Agriculture, Natural Resources and Design, West Virginia University.
} 


\section{Introduction}

New firm formation in the market implies important phenomenon of invention of new products, improvement in production processes, and increased competition in the market (Fritsch, 1997; Mata and Portugal, 1994). An increase in the number of new firms is expected to have positive effects on regional employment (Fritsch, 1997). Thus, new firm formation is a key element of economic development and growth (Vassar, 2006).

Fritsch and Mueller, (2004) and Henderson (2006) argued that as income level becomes higher, wealth increases, and this elevates markets due to jobs created by new businesses and self-employment. Job creation, a simultaneous process, is positively related with economic growth (Eamets et al., 2005; Mueller et al., 2006). But these positive effects do not appear in the short-run (Fritsch and Mueller, 2004). Commercialization of new ideas and innovations in the market bring new wealth for entrepreneurs (Cabarcos and Rodriguez, 2006; Mojica et al., 2009).

New firm formation vitalizes economic development and employment growth. Efforts to enhance economic development at national and local levels have focused on increasing entrepreneurship. Entrepreneurs play a dominant role in the growth, development and prosperity of the economy. They are a reliable source of technological innovations in production processes. Entrepreneurs form new firms and use different types of business methods such as availability and features of alternative products, technology, and supply of product. These newly formed firms are important for economic activities such as employed resources, labor and capital goods pricing, organizing production, and marketing goods (Schmitz, 1989; Spulber, 2008).

New firm formation is a vital component of economic development and is one of the main indicators of entrepreneurship. It performs an important role in employment creation, innovation, economic development and unemployment reduction. Different surveys showed that the new firm formation rate varies across countries and regions. These variations may have 
important implications in terms of entrepreneurial policies where it is essential to understand the way to increase new firm formation rate in various regions (Choi and Phan, 2006; Venesaar, 2005).

Identifying the most appropriate means to encourage new firm formation, especially in rural areas and enhancing economic development, is a challenging task for private and public decision makers. To encourage new firm formation, it is essential to know about the dynamics between the needs of new firms and economic development because some economic and demographic constraints affect new firm formation and, therefore, affect economic conditions and development of a region. Most of the rural areas in the Northeast region are facing the problem of death of firms which results from the reduction of resource extractive industries; this demise of firms also creates higher unemployment rates, underdevelopment, slow population growth, high poverty rates, and an increasing gap in per capita income between urban and rural areas.

Two main characteristics of the Northeast region are: low population density in rural areas and an increasing gap between rural and urban populations which occur due to serious economic development issues (Goetz, 1999). Some other economic indicators that affect economic development are poverty level and the unemployment rate, especially in rural areas and poor states such as Maine, Vermont, and West Virginia (Yang and Snyder, 2007). The income gap between rural and urban areas is increasing and a considerable proportion of the population is affected by this gap. Almost 7 million people living in rural areas in the region, approximately 11.6 percent of the total population is experiencing the effects of the rural-urban income gap. Thus, the specific objective of the study is to identify and estimate the impacts of new firm formation in the economic development of the Northeast region. 
The study area consists of 299 counties in the states of Connecticut, Delaware, Massachusetts, Maine, Maryland, New York, New Jersey, New Hampshire, Pennsylvania, Rohde Island, Vermont, and West Virginia. The population of the Northeast region is approximately 62 million which is equal to 22 percent of the U.S. population (U.S. Census, 2000). According to the USDA-ERS County Typology (2004), the region has a more urban population with 55 percent of its 299 counties classified as urban. In the region, 94 counties are non-metropolitan and are adjacent to a metropolitan area.

\section{Review of Start-up Business Analysis}

Previous studies have shown that there is a strong relationship between new firm formation and economic development. In other words, an increase in the number of new firms leads to economic development through job creation. Lee et al., (2004) used start-ups of new firms as a measure of entrepreneurship. They represent the relationship between regional social characteristics, human capital, and start-ups of new firms. They argued that a new firm's start-up rate can be higher if it is easy to enter into a regional labor market and there exists a variety of cultures to provide a flow of human capital which encourages innovations and increases information flow. To analyze the creativity and diversity effects on entrepreneurship, two geographic units (Metropolitan Statistical Areas and Primary Metropolitan Statistical Areas) were used. The results showed that new firm start-ups are strongly related to creativity and diversity assuming other variables to remain constant.

Audretsch and Fritsch (2002) explored multiple approaches to determine the relationship between entrepreneurship and regional economic development. They defined four different growth systems (patterns) to achieve the same purpose which were employment creation and economic growth. They argued that growth systems vary over time and space. The reason is that 
some regions had higher growth rates through large firms while other regions had the same level of economic growth through new firm formation. The results showed that some regions achieved higher growth rates by focusing on actively encouraging a high rate of new firm formation. They also concluded that small firms and formation of new firms may not have great importance in the short-run, but they can be significant factors for economic development in the long-run. They suggested that new firm formation should be the focus of economic development in regional policy because it increases regional economic growth.

Kirchhoff and Phillips (1988) explained the significance of new firm formation and economic growth. They explored the role of small and large firms in job creation in the United States. They defined a small firm as a business with less than 100 employees. They concluded that small firms create the major proportion of jobs in the United States. They found that the entry rate of firms varied from time to time and new firm formation became a major reason for an increase in the total number of firms. They showed that a net increase in the number of firms has a positive relationship with economic development. They also found the same relationship between economic growth and job creation and loss. Job creation and loss were described by firm births, expansions, deaths, and contractions. Since the results showed that the firm birth rate is higher than the death rate, it was concluded that new firm formation has an important role in economic development.

Acs and Armington (2004) analyzed the link between regional economic growth and local entrepreneurship. They indicated that entrepreneurship can be used for regional employment growth. Their argument is based on recent growth theories which pay more attention to knowledge and knowledge externalities as basic sources of economic growth rather than scale economies. They also indicated that scale economies function is defined at the plant 
level and knowledge externalities function at the firm level. They concluded that increases in entrepreneurial activities are strongly related to regional economic growth. They also found that new firms play a significant role in economic development which is expected from the manufacturing sector.

Acs and Mueller (2008) estimated the link between business dynamics and employment effects in the U.S. Their study focused on 320 Metropolitan Statistical Areas. They concluded that firm (entry) type and characteristics of the region are crucial for employment growth. They also concluded that initial economic conditions are advantageous for large firms and existing firms at new locations compared with small firms.

Baptista et al. (2008) used regional data to examine and estimate the relationship between new business formation and changes in regional employment by using time differences. They found that although the indirect effect of new firms' start-up is much stronger than any direct effects, indirect effects can only be observed after eight years from the firm start-ups. They found that the effects of new firm start-ups on regional employment growth depend on the types and qualities of start-ups.

Carod et al. (2008) explained the effects of new firms' formation on employment growth in manufacturing industries. The link between new firms formation and economic development in these industries is important but the degree of the link is not clear. They used a time lag to show time period effects of new firms' formation on employment. The results showed new firm formation has positive effects on employment in the short-term, negative in the intermediateterm and positive in the long-term.

Andersson and Noseleit (2008) examined the link between new firm formations and employment. They used longitudinal data over a decade to analyze the relationship between 
start-ups and employment. The results showed that knowledge-based firms have higher effects on the regional economy, especially high-end services such as real estates, finance and insurance, and research and development $(\mathrm{R} \& \mathrm{D})$ services. They concluded that firm start-ups are effective instruments for change in the regional industry.

The studies reviewed in the previous paragraphs estimated the relationships between new firm formation and economic growth. Some analyzed the link between new firm formation and employment growth. Others estimated the relationship between start-ups of firm and new jobs created. However, this study is unique from other studies by its focus on analyzing the relationship between new firm formation and economic development in which the relationship is examined using a Three-Stage Least Squares (3SLS) method to estimate empirically the simultaneous equations model where economic development is represented by changes in population density, employment, and per capita income.

\section{Empirical Model}

As indicated above, the focus of this study is to analyze the relationship between new firm formation and economic development represented by changes in population density, employment, and per capita income. Besides new firm formation, the empirical analysis uses other variables which affect economic development. The study is derived from the two-equation simultaneous model of Carlino and Mills (1987). They build this model by modifying Steinnes' model (1982). Deller et al., (2001) extended it into a three simultaneous equation model which incorporated the interdependencies among changes in population, per capita income, and employment. Some studies extended the Deller et al. model to estimate simultaneous relationships of economic development with entrepreneurship, amenities, environmental regulation, by modeling small business growth, migration behavior, local public services, and 
median household income (Gebremeriam, 2006; Kahsai, 2009, Mojica, 2009; and Nondo, 2009). This study modifies Deller's model by extending it to a four simultaneous equations model.

The general form of the four simultaneous equations model defines the interaction between population density (P), employment (E), Per capita income (Y), and new firm formation $(\mathrm{NF})$ and is specified as:

$$
\begin{aligned}
& P^{*}=f\left(E^{*}, Y^{*}, N F^{*} / X^{P}\right) \\
& E^{*}=f\left(P^{*}, Y^{*}, N F^{*} / X^{E}\right) \\
& Y^{*}=f\left(P^{*}, E^{*}, N F^{*} / X^{Y}\right) \\
& N F^{*}=f\left(P^{*}, E^{*}, E^{*} / X^{N F}\right)
\end{aligned}
$$

Where $P^{*}, E^{*}, Y^{*}$, and $N F^{*}$ represent equilibrium levels of population density, employment, per capita income, and new firm formation, respectively in the ith county; $X^{P}, X^{Y}, X^{E}$, and $X^{N F}$ are a set of exogenous variables that have either direct or indirect effects on population density, employment, per capita income, and new firm formation.

Equations (1a)-(1d) represent population density, employment, per capita income, new firm formation, and exogenous variables $(X s)$ to determine the equilibrium levels of population density, employment, per capita income, and new firm formation. The general equilibrium conditions specified in equations (1a)-(1d) is expressed as a linear relationship and can be explained as:

$$
\begin{aligned}
& P^{*}=\alpha_{0 P}+\beta_{1 P} E^{*}+\beta_{2 P} Y^{*}+\beta_{3 P} N F^{*}+\sum \delta_{1 P} X^{P} \\
& E^{*}=\alpha_{0 E}+\beta_{1 E} P^{*}+\beta_{2 E} Y^{*}+\beta_{3 E} N F^{*}+\sum \delta_{2 E} X^{E} \\
& Y^{*}=\alpha_{0 Y}+\beta_{1 Y} P^{*}+\beta_{2 Y} E^{*}+\beta_{3 Y} N F^{*}+\sum \delta_{3 Y} X^{Y} \\
& N F^{*}=\alpha_{0 N F}+\beta_{1 N F} P^{*}+\beta_{2 N F} E^{*}+\beta_{3 N F} Y^{*}+\sum \delta_{4 N F} X^{N F}
\end{aligned}
$$


Mills and Price (1984) recommended that equilibrium levels of population density, employment, per capita income, and new firm formation are likely to be adjusting with distributed lags. The distributed lag adjustments models are specified as:

$$
\begin{aligned}
& P_{t}=P_{t-1}+\lambda_{P}\left(P^{*}-P_{t-1}\right) \\
& E_{t}=E_{t-1}+\lambda_{E}\left(E^{*}-E_{t-1}\right) \\
& Y_{t}=Y_{t-1}+\lambda_{Y}\left(Y^{*}-Y_{t-1}\right) \\
& N F_{t}=N F_{t-1}+\lambda_{N F}\left(N F^{*}-N F_{t-1}\right)
\end{aligned}
$$

Where the subscript ( $\mathrm{t}-1)$ represents the initial condition of endogenous variables of population density, employment, per capita income and new firm formation and $\lambda_{P}, \lambda_{E}, \lambda_{Y}$, and $\lambda_{N F}$ are speed-of- adjustment coefficients to the desired level of population density, employment, per capita income, and new firm formation. Generally, positive and higher values of these coefficients represent quicker growth rates. Adjustment coefficients are assumed to be $0 \leq \lambda_{P}, \lambda_{E}, \lambda_{Y}, \lambda_{\mathrm{NF}} \leq 1$

Equations (3a)-(3d) indicate that present conditions of population density, employment, per capita income, and new firm formation depend on their initial conditions and a change between equilibrium value and its lagged value. Rearranged equations of (3a)-(3d) are as follows:

$$
\begin{aligned}
& \Delta P=P_{t}-P_{t-1}=\lambda_{P}\left(P^{*}-P_{t-1}\right) \Rightarrow P^{*}=\frac{1}{\lambda_{P}}\left(P_{t}-P_{t-1}\right) \\
& \Delta E=E_{t}-E_{t-1}=\lambda_{E}\left(E^{*}-E_{t-1}\right) \Rightarrow E^{*}=\frac{1}{\lambda_{E}}\left(E_{t}-E_{t-1}\right) \\
& \Delta Y=Y_{t}-Y_{t-1}=\lambda_{Y}\left(Y^{*}-Y_{t-1}\right) \Rightarrow Y^{*}=\frac{1}{\lambda_{\mathrm{Y}}}\left(Y_{t}-Y_{t-1}\right) \\
& \Delta N F=N F_{t}-N F_{t-1}=\lambda_{N F}\left(N F^{*}-N F_{t-1}\right) \Rightarrow N F^{*}=\frac{1}{\lambda_{N F}}\left(N F_{t}-N F_{t-1}\right)
\end{aligned}
$$


In this scenario, $\Delta$ represents a region's change in population density, employment, per capita income, and new firm formation. The changes in endogenous variables are gained from the percentage growth rate between the observations of 1993 and observations of 2008 as expressed below:

$$
\begin{aligned}
& \Delta P=\operatorname{LOG}\left(P_{2008}\right)-\operatorname{LOG}\left(P_{1993}\right) \\
& \Delta E=\operatorname{LOG}\left(E_{2008}\right)-\operatorname{LOG}\left(E_{1993}\right) \\
& \Delta Y=\operatorname{LOG}\left(Y_{2008}\right)-\operatorname{LOG}\left(Y_{1993}\right) \\
& \Delta N F=\operatorname{LOG}\left(N F_{2008}\right)-\operatorname{LOG}\left(N F_{1993}\right)
\end{aligned}
$$

By substituting equations (4a)-(4d) into equations (2a)-(2d), respectively, and rearranging the equations, the linear form of the estimation equations is obtained. This empirical model for estimation consists of four simultaneous equations with respect to population density, employment, per capita income, and new firm formation. These equations are defined as follows:

$$
\begin{aligned}
& \Delta P=\alpha_{0 P}+\beta_{1 P} \Delta E+\beta_{2 P} \Delta Y+\beta_{3 P} \Delta N F+\beta_{4 P} P_{1993}+\beta_{5 P} E_{1993}+\beta_{6 P} Y_{1993} \\
& +\beta_{7 P} N F_{1993}+\sum \delta_{1 P} X^{P}+u_{1} \\
& \Delta E=\alpha_{0 E}+\beta_{1 E} \Delta P+\beta_{2 E} \Delta Y+\beta_{3 E} \Delta N F+\beta_{4 E} P_{1993}+\beta_{5 E} E_{1993}+\beta_{6 E} Y_{1993} \\
& +\beta_{7 E} N F_{1993}+\sum \delta_{2 E} X^{E}+u_{2} \\
& \Delta Y=\alpha_{0 Y}+\beta_{1 Y} \Delta P+\beta_{2 Y} \Delta E+\beta_{3 Y} \Delta N F+\beta_{4 Y} P_{1993}+\beta_{5 Y} E_{1993}+\beta_{6 Y} Y_{1993} \\
& +\beta_{7 Y} N F_{1993}+\sum \delta_{3 Y} X^{Y}+u_{3} \\
& \Delta N F=\alpha_{0 N F}+\beta_{1 N F} \Delta P+\beta_{2 N F} \Delta E+\beta_{3 N F} \Delta Y+\beta_{4 N F} P_{1993}+\beta_{5 N F} E_{1993}+ \\
& \beta_{6 N F} Y_{1993}+\beta_{7 N F} N F_{1993}+\sum \delta_{4 N F} X^{N F}+u_{4}
\end{aligned}
$$

\section{Types and Source of Data}

Secondary data from 1993 to 2008 is used in the study. All the endogenous variables are explained as growth rates from 1993 to 2008. Table 1 provides a description of endogenous variables and initial condition variables and also explains the sources of data. Data for endogenous variables of population density, employment, per capita income, and new firm formation were collected from the U.S. Census Bureau, Bureau of Economic Analysis, Regional 
Economic Information System (REIS), and County and City Data Book (C\&CDB) from 1993 to 2008.

The endogenous variables $\Delta P, \Delta E, \Delta Y$, and $\Delta N F$ indicate county's growth rates in population density, employment, per capita income, and new firm formation, respectively. Error terms are shown by $u_{1}, u_{2}, u_{3}$, and $u_{4}$ and exogenous variable vector is represented by $X$. Initial period (subscript t-1) is 1993. The lag adjustment models assume that endogenous variables are adjusted over a period of time i.e., are not adjusted instantaneously to their equilibrium levels. Deller and Lledo (2007) and Deller et al. (2001) identified that the speed of adjustment coefficients are embedded in the coefficients of $\alpha, \beta$, and $\delta$. This framework permits researchers to estimate structural relationships while simultaneously isolating the effects of new firm formation on regional economic development. Thus, the estimation of equations (6a) to (6d) is from a short-run adjustment of population density, employment, per capita income, and new firm formation to long-run equilibriums $\left(P^{*}, E^{*}, Y^{*}\right.$, and $\left.N F^{*}\right)$. The equations used in the empirical model are explained in detail below:

\subsection{Population Density Equation}

The endogenous variable, growth in population density $(G R P O P)$, is defined as the difference in the log values of population density between 2008 and 1993 in ith county. Growth in population density $(G R P O P)$ also is described as a function of initial conditions of dependent variables; growth in employment $(G R E M P)$, growth in per capita income (GRPCI), and growth in new firm formation $(G R N F)$; and their interaction terms. It is hypothesized that growth in

\section{[Insert Table 1]}

population density over time has a negative relationship with initial condition of population. This negative relationship explains that growth in population density is slower in the counties with 
high levels of population density compared to the counties that have lower levels of population. The initial conditions of dependent variables are population density in 1993 in ith county (POPBASE), employment in 1993 in ith county (EMPBASE), per capita income in 1993 in ith county (PCIBASE), and firm start-ups in 1993 in ith county (NFBASE).

The population density equation contains other control variables such as per capita income taxes (PCITAX), per capita local government expenditure (EGOV), poverty rate (POVERTY), median housing values (CMHV), and crime rate (CRIME). It is hypothesized that growth in population density has a negative relationship with PCITAX as it refers to an additional cost to households and firms and stimulates out-migration. Government expenditure increases public goods and services provision such as highways, education, health, and public safety services (police, fire departments, etc.) and, as a result, per capita government expenditure $(E G O V)$ is expected to have a positive relationship with population density growth. Poverty rate (POVERTY) is hypothesized to have a negative relationship with population density growth because a high poverty rate in ith county indicates that a high percentage of the population density is below the poverty line. Cost of living cost in ith county is represented by county's median housing value $(C M H V)$. High median housing value has a negative relationship with population density growth and a low median housing value has a positive relationship with population density growth. Crime rate (CRIME) is hypothesized to have a negative relationship with population density growth because a high rate of violent crimes encourages out-migration.

$$
\begin{aligned}
& \text { GRPOP }=\beta_{0}+\beta_{1} G R E M P+\beta_{2} G R P C I+\beta_{3} G R N F+\beta_{4} P O P B A S E+ \\
& \beta_{5} E M P B A S E++\beta_{6} P C I B A S E+\beta_{7} N F B A S E+\beta_{8} P O V E R T Y+\beta_{9} C R I M E \\
& +\beta_{10} P C I T A X+\beta_{11} E G O V+\beta_{12} C M H V+\varepsilon_{1}
\end{aligned}
$$




\subsection{Employment Equation}

Growth in employment (GREMP) is defined as the difference in the log values of employment between 1993 and 2008. Growth in employment is defined as a function of growth in population density $(G R P O P)$, growth in per capita income (GRPCI), and growth in new firm formation $(G R P N F)$; initial conditions of employment (EMPBASE) and per capita income (PCIBASE); and some control variables included to measure economic effects. Per capita local government expenditure $(E G O V)$ increases public goods and services provision. As a control variable of economic effect, it is hypothesized that local government expenditure has a positive relationship with employment growth. Per capita income tax (PCITAX), another economic variable, is included as a control variable and hypothesized to have a negative relationship with employment growth. Number of firms (NFIRM) in ith county is hypothesized to have a positive impact on employment due to its demand for labor. A high median housing value $(C M H V)$ is expected to have a negative relationship with employment growth and a low median housing value to have a positive relationship with employment growth.

Another important variable, percentage of population of 25 years of age with bachelor's degree or higher education $(C O L L D)$, captures the effects of educational attainment and represents the human capital variable. It is included in the employment equation as a control variable. As educational attainment increases productivity and entrepreneurial ability and the skills of individuals increase, so COLLD is expected to have a positive relationship with employment. Entrepreneurial ability and skills can be a motivation for expansion of existing firm and start-up of new firms as well.

An availability variable included in the employment equation is interstate road density $(R O A D D E N)$. It is hypothesized that interstate road density (ROADDEN) will have a positive 
relationship with employment growth since it estimates the extent and coverage of the paved road infrastructure in ith county and it is linked with improved mobility.

$$
\begin{aligned}
& \text { GREMP }=\beta_{0}+\beta_{1} G R P O P+\beta_{2} G R P C I+\beta_{3} G R N F+\beta_{4} E M P B A S E+ \\
& \beta_{5} \text { PCIBASE }+\beta_{6} \text { PCITAX }+\beta_{7} E G O V+\beta_{8} C M H V+\beta_{9} C O L L D+\beta_{10} N F I R M S \\
& +\beta_{11} R O A D D E N+\varepsilon_{2}
\end{aligned}
$$

\subsection{Per capita income Equation}

Growth in per capita income $(G R P C I)$ is defined as the difference in the log values of per capita income between 2008 and 1993. Growth in per capita income (GRPCI) is also defined as a function of growth in population density $(G R P O P)$ and growth in new firm formation $(G R N F)$; initial conditions of per capita income (PCIBASE), and new firm formation (NFBASE); and some control variables included to measure economic effects.

Growth in number of proprietors $(G R P R O)$, as a control variable, is hypothesized to have a positive relationship with growth in per capita income. Per capita income tax (PCITAX), another important control variable, is expected to have a negative relationship with per capita income. Slow growth in per capita income leads to high poverty rate. It is hypothesized that poverty rate $(P O V E R T Y)$ is expected to have a negative effect on per capita income. The number of firms (NFIRM) in ith county is hypothesized to have positive impacts on per capita income due to their demand for labor. Government expenditures (EGOV) is used in providing public good and services such as highways, education, health, and public safety services (police, fire departments, etc.) and is expected to have a negative relationship with per capita income growth.

Percentage of population between 18 and 65 years of age represents active labor force (OPERATIVE) and the percentage of population of 25 years of age or over with bachelor's degree or higher education $(C O L L D)$ captures the educational attainment effects and represent human capital variables; both are included in per capita income equation as control variables. It 
is hypothesized that OPERATIVE affects per capita income positively because at higher level more of the OPERATIVE population's income is from wages and salaries. Since educational attainment is expected to increase productivity and entrepreneurial ability and skills of individuals, COLLD is expected to have positive relationship with per capita income. Another control variable that measures demographic effects is percentage of population over 65 years representing retired labor force (RETIRE). It is hypothesized that RETIRE will have a negative relationship with per capita income because a main source of income for retired people is social security benefits.

$$
\begin{aligned}
& \text { GRPCI }=\beta_{0}+\beta_{1} \text { GRPOP }+\beta_{2} \text { GRNF }+\beta_{3} \text { PCIBASE }+\beta_{4} \text { NFBASE }+ \\
& \beta_{5} \text { GRPRO }+\beta_{6} \text { POVERTY }+\beta_{7} \text { PCITAX }+\beta_{8} E G O V+\beta_{9} C O L L D+ \\
& \beta_{10} \text { NFIRMS }+\beta_{11} \text { RETIRE }+\beta_{12} \text { OPERATIVE }+\varepsilon_{3}
\end{aligned}
$$

\subsection{New Firms Formation Equation}

Growth in new firms $(G R N F)$ is defined as the difference in the log values of number of new firms between 2008 and 1993. Growth in new firm formation $(G R N F)$ also is defined as a function of growth in population density (GRPOP), growth in employment (GREMP) and growth in per capita income (GRPCI). Initial conditions of per capita income (PCIBASE), and new firms (NFBASE), and some control variables are included to measure economic effects.

The new firm formation equation contains control variables including the poverty rate (POVERTY), which is hypothesized to have a negative relationship with the new firm formation. Other variables such as intensity of industry (INTENSITY), firm density (FIRMDEN), survival rate of firms (SURVIVAL), number of dead firms per county (DEATHS), number of new workers (WORKER), and size of firms (SIZE), are used in the new firm formation equation. It is hypothesized that $D E A T H$ has a negative relationship with new firm formation. The variation in number of new firm density, due to population density, is an important aspect. INTENSITY is 
used and hypothesized to be positively related to GRNF. To control for the size distribution of employees, SIZE is hypothesized to be positively related with new firm formation. Most of the new employment is created by small and rapid growth of enterprises. Almost 66 percent of all new jobs were created by such firms in the U.S. during 1979 (Bhide, 2000). Therefore, it is hypothesized that WORKER and FIRMDEN have positive relationships with new firm formation. Since a high survival rate of firms encourages more people to start their businesses as proprietors, it is hypothesized that the relationship between SURVIVAL and new firm formation will be positive. It is expected to be positive only if survival rate is high, otherwise the relationship is negative.

$$
\begin{aligned}
& \text { GRNF }=\beta_{0}+\beta_{1} \text { GRPOP }+\beta_{2} \text { FREMP }+\beta_{3} \text { GRPCI }+\beta_{4} \text { PCIBASE }+ \\
& \beta_{5} N F B A S E+\beta_{6} \text { POVERTY }+\beta_{7} I N T E N S I T Y+\beta_{8} \text { WORKER }+\beta_{9} \text { FIRMDEN } \\
& +\beta_{10} \text { SURVIVAL }+\beta_{11} \text { DEATH }+\beta_{12} \text { SIZE }+\varepsilon_{4}
\end{aligned}
$$

\section{Empirical Results and Analysis}

The empirical model analyzes the relationship between new firm formation and economic development in the northeast region. In this study economic development is represented by population density, employment, and per capita income. The three stages least square (3SLS) method is used to overcome the problem of correlation of error term of each equation. 3SLS takes into account all restriction on parameters in the simultaneous equations system. The results are given in Table 2 .

\subsection{Population Density Equation}

The population density growth equation is estimated against three other endogenous variables (growth rate of employment, per capita income, and new firm formation), the lagged value of all four endogenous variables, and control variables included to measure economic effects. An increase in the number of jobs attracts in-migration. Results show that growth in 
population density (GRPOP) is positively and significantly related with growth rate of employment (GREMP) which explains that an increase in number of jobs also increases population. A negative relationship of GRPOP and growth in per capita income (GRPCI) indicates that in the Northeast region of the United States population density increases as per capita income decreases. As the number of new firms increases the demand for labor also increases which leads to in-migration. Thus, there is a positive and significant relationship between GRPOP and new firm formation $(G R N F F)$.

One of the main assumptions of empirical model was the dependence of growth on initial conditions of endogenous variables. The initial value of employment (EMPBASE) indicates a significant and negative relationship with GRPOP. It implies that counties with high employment have low population density growth rates compared to counties with low initial employment. The initial value of new firm formation (NFFBASE) presents a positive and significant relationship with GRPOP. This relationship implies that counties with initially less new firms in 1993 are experiencing faster growth in population density than counties which had a large number of firms.

The relationship between per capita income tax $(P C I T A X)$ and GRPOP is negative and significant at 5 percent level. Per capita property tax $(P R T A X)$ has a negative relationship with GRPOP and is significant at 1 percent level. County's median housing value (CMHV) and GRPOP are positively and significantly related to each other. Local government spending programs such as investment in education, health care, highways, and crime prevention, enhance population density growth in that county. However, the negative link between local government expenditures $(E G O V)$ and $G R P O P$ was unexpected. A positive coefficient of violent crime rate (CRIME) shows that the nature of crimes reported may not cause out-migration. 


\subsection{Employment equation}

The employment growth equation is estimated against the other three endogenous variables (growth rate of population density, per capita income, new firm formation), the initial conditions of two endogenous variables (employment and per capita income), and control variables included to measure economic effects. Results show that growth rate of employment $(G R E M P)$ is positively related with growth rate of population density (GRPOP) and are significant at 1 percent level. This result indicates that jobs follow people. However, the population density growth rate in the Northeast region is low indicating less supply of labor and ultimately wage rate increases. Consequently, firms do not have any option other than employing labor with high wages. Hence, a positive and significant relationship between GREMP and GRPCI is expected.

The initial level of employment (EMPBASE) is positively and significantly linked with GREMP. This result shows that counties with low employment density in 1993 gain low employment growth compared to counties with high employment density in 1993. Although, the coefficient is significant at 1 percent level, the result is not as expected. An increase in per capita income tax (PCITAX) raises more revenue for government and ultimately is used in the provision of local government spending programs such as education, health care, highways, and crime prevention etc. The positive and significant relationship between local government expenditure $(E G O V)$ and GREMP is as expected.

An increase in median housing value $(C M H V)$ helps people to make a decision to not move to start a job since the living cost is too high in that county. To this effect, there is a negative and significant relationship between $C M H V$ and GREMP. Some control variables did not measure economic effects as expected, such as, the number of firms (NFIRM) and GREMP 
which are negatively and significantly linked with each other indicating that the existing firms did not expand their businesses. The percentage of population above 25 years of age with a college degree $(C O L L D)$ seems to have no significant economic effect on employment growth in the Northeast region.

\subsection{Per capita income equation}

The per capita income growth equation is estimated against two endogenous variables; growth in population density (GRPOP) and growth in new firm formation (GRNF, the initial conditions of growth in per capita income (GRPCI) and growth in new firms (GRNFF); and some control variables are included to measure economic effects. Results show that growth in population density $(G R P O P)$ is negatively related with growth rate of per capita income $(G R P C I)$ and explains that as population density increases the growth rate of per capita income decreases. As the number of new firms increases in a certain county, the demand for labor also increases which leads to an increase in per capita income in the county. Job opportunities for unemployed or under-employed people increase due to increase in the number of proprietors. This implies a positive relationship between GRPCI and growth rate of the number of proprietors $(G R P R O)$. The empirical results confirm that there is a positive and significant link between GRPCI and GRPRO.

The coefficient for initial conditions of the number of new firms (NFFBASE) is significant and has positive effects on GRPCI. This result indicates that counties with large number of new firms lead to higher per capita income which is directly related to economic growth. Initial conditions of per capita income (PCIBASE), have a negative link with GRPCI, and indicate that counties with low levels of income in 1993 have had higher growth rates compared to counties with higher income in 1993. The coefficient of poverty rate (POVERTY) 
has a negative sign indicating an inverse relationship with growth in per capita income. The coefficient of number of existing firms (NFIRMS) is positive and significant at a 5 percent level.

An increase in educational attainment $(C O L L D)$ increases the number of skilled laborers in the county. Since skilled labor earns more than unskilled labor, there is a positive and significant link between COLLD and GRPCI. The active population represented by the

percentage of population between 18 years and 65 years of age (OPERATIVE) derive most of their income from wage and salaried jobs. Hence, OPERATIVE is positively and significantly related to GRPCI. Since the main source of income for a retired population (RETIRE) generally is social security benefits, a large number of retired population in a county leads to slow growth in per capita income.

\subsection{New firm formation equation}

The new firm formation growth $(G R N F F)$; equation is estimated against three endogenous variables (growth in population, employment and per capita income); the initial conditions of growth in per capita income (PCIBASE) and the initial conditions of growth in new firm formation (NFFBASE) and control variables included to measure economic effects. Empirical results show that growth in population density $(G R P O P)$ is positively and significantly related with growth in new firm formation $(G R N F F)$. It implies that as population density increases, large supply of labor is available which attracts entrepreneurs to start their businesses in that county. There is a negative and significant relationship between growth in employment (GREMP) and GRNFF. A positive relationship between GRPCI and growth in new firms $(G R N F F)$ confirms a positive link between GRPCI and GRNFF as expected.

The coefficient of the initial condition for new firm formation (NFFBASE) is significant and has a negative effect on GRNFF. It implies that a large number of firms in 1993 indicates a 
possibly high wage rate and discourages entrepreneurs to start new businesses. The coefficient of initial condition of per capita income (PCIBASE) is positive and significant at 1 percent. This implies that counties with low levels of income in 1993 have a high rate of new firm formation compared to counties with higher level of income in 1993. The coefficient for firm density (INTENSITY) is negative and significant at 5 percent level. There is always need for more proprietors/managers, if the size of the businesses increase. To this effect, as the size of existing firms increase, entrepreneurs are induced to start new businesses.

[Insert Table 2]

Similarly, if the survival rate of firms over five years increases, the number of new firms also increases. Thus, there is a positive relationship between survival rates of firms (SURVIVAL) and growth in new firm formation $(G R N F F)$.

\section{Summary and Conclusions}

As indicated earlier, the main objective of this study is to examine the link between new firm formation and economic development in the Northeast region of the United States. The overall conclusion of the study is that, new firm formation is positively related with regional economic development from 1993 to 2008. To estimate the empirical model, a database of new firm formation, socio-economic, demographic, and economic variables of the Northeast region from 1993 to 2008 are collected. New firm formation can be considered as an important tool to reduce poverty, unemployment, and to enhance economic development. New firms create jobs which increase per capita income and increase the welfare of the society.

In the population density growth equation, an increase in employment and new firm formation leads to an increase in population density growth . However, an increase in per capita income results in reduction in population density in the Northeast region. A county's median housing value positively influences growth in population density in the region. Per capita income 
tax negatively affects growth in population. However, poverty rate and per capita government expenditure did not have significant effects on population density growth.

In the employment growth equation, increases in growth in population density and per capita income also increase the employment growth rate. However, an increase in new firm formation leads to a decrease in employment which was unexpected, but the coefficient for new firm formation is not significant. A high per capita income tax is found to reduce the number of new jobs created. A county's median housing value and the number of existing firms negatively influenced employment growth. However, educational attainment and per capita government expenditure show the positive effects on county's employment growth.

In the per capita income growth equation, population density growth negatively affects per capita income. New firm formation positively affects per capita income growth indicating that an increase in the number of firms creates jobs which ultimately increases per capita income. An increase in the number of self-employed proprietors and increases in per capita income are positively and significantly related to income growth. The share of population between 18 and 64 years of age and the share of population above 65 , both have positive relationships with per capita income. The empirical results also indicate that educational attainments and number of existing firms have negative relationships with per capita income.

In the new firm formation growth equation, population density growth and per capita income growth positively affect new firm formation growth. However, employment growth negatively affects new firm formation growth. The poverty rate is negatively related to new firm formation meaning that an increase in the poverty rate reduces growth in the number of new firms created in the county. Some other factors such as new jobs created, firms' density towards land area of the county, size of firms and survival rate of firms were positively linked with new 
firm formation growth. However, firms' density towards population density has negative effects on new firm formation growth.

As explained earlier, the main objective of this study is to estimate the relationship between new firm formation and regional economic development in the Northeast region of the United States. To estimate the empirical model explaining the relationship between new firm formation and economic development indicators (growth in population density, employment, and per capita income), a system of simultaneous equations has been used. Based on the estimated results, the general conclusion of the study is that new firm formation is positively related to economic development from 1993 to 2008. This research contributes by providing policy makers with the information on the relationship between new firm formation and economic development in the Northeast region. New firm formation was hypothesized to play a positive role in the economic development of the Northeast region of the United States. The positive relationship between new firm formation and growth in population density indicate that large population shows cheap supply of labor which attracts businessmen to start new businesses. However, empirical results indicate a negative relationship between new firm formation and employment growth. The positive relationship between new firm formation and growth in per capita income indicates the creation of jobs through new firms which lead to increase of per capita income. Thus, from the empirical findings presented above it is evident that new firm formation plays an important role in enhancing economic development in the region. 
Table 1: Definition of Endogenous and Exogenous Variables

\begin{tabular}{|l|l|l|}
\hline Variable Name & Variable Definitions & Source \\
\hline$\Delta P$ & Growth in population density from 1993 to 2008 & $\begin{array}{l}\text { C\&CDB } \\
\text { CComputed }\end{array}$ \\
\hline$\Delta E$ & Growth in employment from 1993 to 2008 & BEA / Computed \\
$\Delta Y$ & Growth in per capita income from 1993 to 2008 & $\begin{array}{l}\text { C\&CDB / } \\
\text { Computed }\end{array}$ \\
\hline$\Delta N F$ & Growth in number of new firms from 1993 to 2008 & BEA/Computed \\
\hline POPBASE & Population density 1993 & C\&CDB \\
\hline EMPBASE & Employment 1993 & BEA \\
\hline PCBASE & Per capita income 1993 & C\&CDB \\
\hline NFBASE & number of new firms from 1993 & BEA \\
\hline PCITAX & Per capita income tax & C\&CDB \\
\hline GRPRO & Growth in number of proprietors from 1993 to 2008 & BEA \\
\hline POVERTY & Percentage of all age population below poverty & US Census \\
\hline CRIME & Serious crime rate & C\&CDB \\
\hline CMHV & County's median housing value & C\&CDB \\
\hline COLLD & $\begin{array}{l}\text { Percentage of population over 25 year with bachelor } \\
\text { degree of higher }\end{array}$ & C\&DB \\
\hline EGOV & Per capita government expenditures & C\&CDB \\
\hline NFIRM & Number of existing firms per county & USBS \\
\hline ROADDEN & Inter-state road density & NRAC \\
\hline OPERATIVE & Percentage of population between 18 and 64 years & C\&CDB \\
\hline RETIRE & Percentage of population above 65 year & C\&CDB \\
\hline WORKER & $\begin{array}{l}\text { Ratio of new employers in the county per 1000 in the } \\
\text { labor force }\end{array}$ & BDS/Computed \\
\hline INTENSITY & $\begin{array}{l}\text { Number of firm per county divided by land area of } \\
\text { county }\end{array}$ & BDS/Computed \\
\hline SIZE & Firm size with less than 500 employees per county & USBS \\
\hline SURVIVAL & Number of firms survived for five years & USBS/ Computed \\
\hline FIRMDEN & $\begin{array}{l}\text { Number of firms per county divided by population of } \\
\text { county }\end{array}$ & USBS/ Computed \\
\hline DEATHS & Death of existing firms per county & BEA \\
\hline
\end{tabular}


Table 2: New Firm Formation and Economic Development Results

\begin{tabular}{|c|c|c|c|c|c|c|c|c|}
\hline \multirow[b]{2}{*}{ Variables } & \multicolumn{2}{|l|}{ GRPOP } & \multicolumn{2}{|l|}{ GREMP } & \multicolumn{2}{|l|}{ GRPCl } & \multicolumn{2}{|l|}{ GENFF } \\
\hline & Coefficient & z-stat & Coefficient & $\begin{array}{l}\text { z- } \\
\text { stat }\end{array}$ & Coefficient & z-stat & Coefficient & z-stat \\
\hline GRPOP & & & $.9472161^{*}$ & 5.72 & $-.8697087 * * *$ & -1.87 & $1.349285^{*}$ & 8.22 \\
\hline GREMP & $.4366328 *$ & 4.04 & & & & & $-.3736945 * * *$ & -1.85 \\
\hline GRPCl & -.0500876 & -1.21 & $.1203598^{* *}$ & 1.99 & & & .0634076 & 1.08 \\
\hline GRNFF & $.4498991^{*}$ & 4.19 & -.1813668 & -1.26 & $.7978922^{*}$ & 2.61 & & \\
\hline GRPRO & & & & & $.1124924 *$ & 8.38 & & \\
\hline POPBASE & -.0337671 & -1.18 & & & & & & \\
\hline EMPBASE & $-.116398^{*}$ & -4.36 & $.2929586 *$ & 2.85 & & & & \\
\hline PCIBASE & .0125052 & 0.23 & .0254543 & 0.32 & $-.9097827 *$ & -6.69 & -.0183922 & -1.20 \\
\hline NFFBASE & .119148* & 3.26 & & & $.3609846^{*}$ & 3.22 & $-.362212^{*}$ & -5.52 \\
\hline POVERTY & .0005329 & 0.75 & & & -.0006339 & -0.34 & $-.0020358 *$ & -2.43 \\
\hline CRIME & .0050341 & 1.18 & & & & & & \\
\hline PCITAX & $-.014889 * *$ & -2.00 & $.0298158 * *$ & 2.04 & $.0527515^{*}$ & 2.89 & & \\
\hline EGOV & -.0047933 & -1.02 & .0100458 & 1.00 & .0206389 & 1.59 & & \\
\hline CMHV & $.0726143^{* * *}$ & 1.78 & $-.1383792 *$ & -2.27 & & & & \\
\hline COLLD & & & .000447 & 0.67 & $-.003598^{*}$ & -3.15 & & \\
\hline NFIRMS & & & $-.2495172 *$ & -2.41 & $-.2411671^{* *}$ & -2.19 & & \\
\hline ROADDEN & & & -.0012187 & -0.05 & & & & \\
\hline OPERATIVE & & & & & $2.121543^{*}$ & 7.00 & & \\
\hline RETIRE & & & & & $.1853986 * * *$ & 1.90 & & \\
\hline INTENSITY & & & & & & & $-.1111345^{* *}$ & -2.15 \\
\hline WORKER & & & & & & & .0033547 & 1.30 \\
\hline FIRMDEN & & & & & & & .0042293 & 0.45 \\
\hline SURVIVAL & & & & & & & .0848094 & 1.20 \\
\hline DEATH & & & & & & & .075715 & 1.37 \\
\hline SIZE & & & & & & & $.3002709 *$ & 4.87 \\
\hline $\mathrm{N}$ & 299 & & 299 & & 299 & & 299 & \\
\hline $\mathrm{R}^{2}$ & 0.5053 & & 0.6407 & & 0.8888 & & 0.8023 & \\
\hline
\end{tabular}




\section{References}

Acs, ZJ and C Armington (2004). Employment Growth and Entrepreneurial Activity in Cities. Max Planck Institute of Economics: Discussion Paper Entrepreneurship, Growth and Public Policy Group.

Acs, Z and P Mueller (2008). Employment Effects of Business Dynamics: Mice, Gazelles and Elephants. Small Business Economics, 30(1), 85-100.

Andersson, M and F Noseleit (2008). Start-Ups and Employment Growth - Evidence from Sweden. Working Paper Series in Economics and Institutions of Innovation, Royal Institute of Technology, CESIS-Centre of Excellence for Science and Innovation Studies.

Audretsch, D and M Fritsch (2002). Growth Regimes over Time and Space. Regional Studies, 36(2), 113-124.

Baptista, R, V Escária, and P Madruga (2008). Entrepreneurship, Regional Development and Job Creation: The Case of Portugal. Small Business Economics, 30(1), 49-58.

Bhide, A (2000). The Origin and Evaluation of New Businesses. New York: Oxford University Press.

Cabarcos, MÁL and PV Rodríguez (2006). Enterprising Vocation in Europe: The Spanish Case. International Journal of Entrepreneurship, 10, 71.

Carod, J, D Liviano Solís, and M Bofarull (2008). New Business Formation and Employment Growth: Some Evidence for the Spanish Manufacturing Industry. Small Business Economics, 30, 73-84.

Carlino, GA and ES Mills (1987). The Determinants of County Growth. Journal of Regional Science 27(1): 39.

Choi, Y and P Phan (2006). The Influences of Economic and Technology Policy on the Dynamics of New Firm Formation. Small Business Economics, 26(5), 493-503.

Deller, SC, TH Tsai, DW Marcouiller, and DBK English (2001). The Role of Amenities and Quality of Life In Rural Economic Growth. American Journal of Agricultural Economics, 83(2), 352-365.

Deller, SC and V Lledo (2007). Amenities and Rural Appalachia Economic Growth. Agricultural and Resource Economic Review, 36, 107-132.

Eamets, R, J Masson, and K Philips (2005). Job Creation and Job Destruction in Estonia: Labour Reallocation and Structural Changes. Discussion Paper, Institute for the Study of Labor. 
Fritsch, M (1997). New Firms and Regional Employment Change. Small Business Economics, 9(5), 437-448.

Fritsch, M and P Mueller (2004). Effects of New Business Formation on Regional Development over Time. Regional Studies, 38(8), 961-975.

Gebremeriam, GH (2006). Modeling Small Business Growth, Migration Behavior, Local Public Services and Median Household Income in Appalachia: A Spatial Simultaneous Equations Approach. Ph. D. Dissertation, West Virginia University.

Goetz, S (1999). Rural Development Issue in the Northeast: 2000 - 2005. Rural Development Paper No. 2, The Northeast Regional Center for Rural Development.

Henderson, J (2006). Understanding Rural Entrepreneurship at the County Level: Data Challenges. Presented at the Frameworks for Entrepreneurship Research in Food, Agriculture and Rural Development Workshop.

Kahsai, MS (2009). An Analysis of Amenity-Led Rural Economic Development in Northeast Region: A Spatial Simultaneous Equations Approach. Ph.D. Dissertation, West Virginia University.

Kirchhoff, B and B Phillips (1988). The Effect of Firm Formation and Growth on Job Creation in the United States. Journal of Business Venturing, 3(4), 261-272.

Lee, SY, R Florida, and ZJ Acs (2004). Creativity and Entrepreneurship: A Regional Analysis of New Firm Formation. Regional Studies, 38(8), 879-891.

Mata, J and P Portugal (1994). Life Duration of New Firms. The Journal of Industrial Economics, 42(3), 227-245.

Mills, ES and R Price (1984). Metropolitan Suburbanization and Central City Problems. Journal of Urban Economics, 15(1), 1-17.

Mojica, M (2009). Examining the Role of Entrepreneurship in Economic Development in Appalachia. Ph.D. Dissertation. West Virginia University.

Mojica, M, TG Gebremedhin, and PV Schaeffer (2009) An Empirical Analysis of the Link between Entrepreneurship and Economics Growth in West Virginia. Selected Paper prepared for presentation at the Southern Agricultural Economics Association Annual Meeting, Atlanta, Georgia.

Mueller, P, A van Stel, and D Storey (2008). The Effects of New Firm Formation on Regional Development Over Time: The Case of Great Britain. Small Business Economics, 30(1), 59-71. 
Nondo, C (2009). An Empirical Analysis of the Interactions between Environmental Regulations and Economic Growth. Ph.D. Dissertation. West Virginia University.

Schmitz, JA (1989). Imitation, Entrepreneurship, and Long-Run Growth. The Journal of Political Economy, 97(3), 721-739.

Spulber, DF (2008). Entrepreneurs in the Theory of the Firm. Prepared for presentation at the AEA Annual Meetings, New Orleans.

Steinnes, DN (1982). Do People Follow Jobs or Do Jobs Follow People ? A Causality Issue in Urban Economics. Urban Studies, 19(2), 187-192.

Venesaar, U (2006). Regional New Firms Formation and Entrepreneurship Policy in Estonia. Tallinn University of Technology and Estonian Science Fund.

Yang, TC and RA Snyder (2007). Population Change in the Northeast, 2000-2005. RDP No. 39, The Northeast Regional Center for Rural Development. 